\title{
ON A HALF-DISCRETE MULHOLLAND-TYPE INEQUALITY
}

\author{
BICHENG YANG AND WING-SUM CHEUNG
}

Abstract. By means of weight functions and Hadamard's inequality, a half-discrete Mulhollandtype inequality with a best constant factor is given. A best extension with multi-parameters, some equivalent forms as well as the operator expressions are also considered. Mathematics subject classification (2010): 26D15, 47A07.

Keywords and phrases: Mulholland-type inequality, weight function, equivalent form.

\section{REFERENCES}

[1] G. H. Hardy, J. E. Littlewood, G. Pólya, Inequalities, Cambridge University Press, Cambridge, 1934.

[2] D. S. Mitrinović, J. E. PeČArić, A. M. FinK, Inequalities involving functions and their integrals and derivatives, Kluwer Acaremic Publishers, Boston, 1991.

[3] B. YANG, Hilbert-type integral inequalities, Bentham Science Publishers Ltd., 2009.

[4] B. YAng, Discrete Hilbert-type inequalities, Bentham Science Publishers Ltd., 2011.

[5] B. YANG, An extension of Mulholand's inequality, Jordan Journal of Mathematics and Statistics 3, 3 (2010), 151-157.

[6] B. YANG, On Hilbert's integral inequality, Journal of Mathematical Analysis and Applications 220 (1998), 778-785.

[7] B. YANG, The norm of operator and Hilbert-type inequalities, Science Press, Beijin, 2009 (China).

[8] B. YAng, I. BRnetić, M. KRnić, J. PeČARIĆ, Generalization of Hilbert and Hardy-Hilbert integral inequalities, Math. Ineq. and Appl. 8, 2 (2005), 259-272.

[9] M. Krnić, J. Pečarić, Hilbert's inequalities and their reverses, Publ. Math. Debrecen 67, 3-4 (2005), 315-331.

[10] J. Jin, L. Debnath, On a Hilbert-type linear series operator and its applications, Journal of Mathematical Analysis and Applications 371 (2010), 691-704.

[11] L. AZAR, On some extensions of Hardy-Hilbert's inequality and Applications, Journal of Inequalities and Applications 2009, no. 546829.

[12] B. YANG, T. RASSIAS, On the way of weight coefficient and research for Hilbert-type inequalities, Math. Ineq. Appl. 6, 4 (2003), 625-658.

[13] B. Arpad, O. Choonghong, Best constant for certain multilinear integral operator, Journal of Inequalities and Applications 2006, no. 28582.

[14] J. Kuang, L. Debnath, On Hilbert's type inequalities on the weighted Orlicz spaces, Pacific J. Appl. Math. 1, 1 (2007), 95-103.

[15] W. ZHONG, The Hilbert-type integral inequality with a homogeneous kernel of Lambda-degree, Journal of Inequalities and Applications 2008, no. 917392.

[16] Y. LI, B. HE, On inequalities of Hilbert's type, Bulletin of the Australian Mathematical Society 76, 1 (2007), 1-13.

[17] B. YANG, A mixed Hilbert-type inequality with a best constant factor, International Journal of Pure and Applied Mathematcs 20, 3 (2005), 319-328.

[18] B. YANG, A half-discrete Hilbert's inequality, Journal of Guangdong University of Education 31, 3 (2011), 1-7.

[19] J. KuAnG, Applied inequalities, Shangdong Science Technic Press, Jinan, 2004 (China).

[20] J. KuANG, Introduction to real analysis, Hunan Education Press, Chansha, 1996 (China). 